\title{
A New Current Balancer in Single-Phase Three-Wire Secondary Distribution Feeders Using the Correlation Coefficients
}

\author{
Toshihiko Tanaka Member (Yamaguchi University, totanaka@yamaguchi-u.ac.jp) \\ Hirokazu Fukui Student Member (Yamaguchi University, h.fukui@pe-news1.eee.yamaguchi-u.ac.jp) \\ Eiji Hiraki Member (Yamaguchi University, hiraki@yamaguchi-u.ac.jp) \\ Shuuji Watanabe Member (Matsue National College of Technology, wata-sj@matsue-ct.ac.jp) \\ Shinji Fukuma Non-member (Fukui University, fukuma@fuis.fuis.fukui-u.ac.jp)
}

Keywords: correlation coefficient, active current, single-phase secondary distribution feeder, current balancer, three-leg voltage-

source PWM converter

This paper proposes a new current balancer in single-phase secondary distribution feeders using the three-leg PWM converter. A new control method for the proposed current balancer with the correlation coefficients is also proposed. The basic principle of the proposed current balancer with the proposed control method is discussed in detail, then confirmed by digital computer simulation using PSIM software. A prototype experimental model is constructed and tested to verify the validity and practicability of the proposed current balancer.

Fig. 1 shows a circuit diagram of the constructed experimental model of the proposed current balancer in single-phase secondary distribution feeders. The three-leg PWM converter that performs a current balancer is connected in parallel to the loads. The source voltage $v_{S}$, the load currents $i_{L 1}$ and $i_{L 2}$ are detected, and then the components of the load currents correlative to the source voltage waveform, which correspond to the active currents, are calculated in each feeder by a DSP (digital signal processor: TMS320C6713).

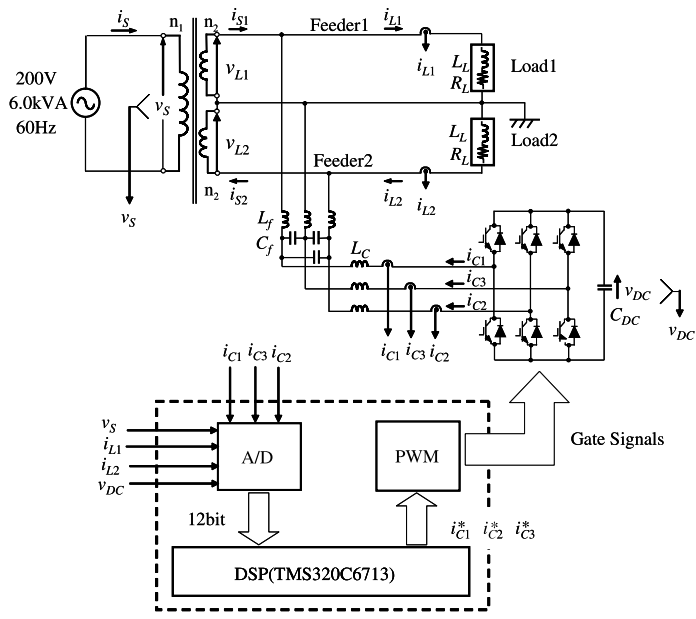

Fig. 1. Circuit diagram of the constructed experimental model of the proposed current balancer in single-phase secondary distribution feeders
The reactive and unbalanced-active components are compensated on the source side. The balanced currents with unity power factor are obtained in each feeder.

Fig. 2 shows experimental results for Fig. 1, where the unbalanced loads are connected. Before the current balancer was started, the source currents $i_{S 1}$ and $i_{S 2}$ were unbalanced, and their power factors were not unity, respectively. After the current balancer was started, the source currents $i_{S 1}$ and $i_{S 2}$ were balanced with the unity power factor in spite of the unbalanced load currents $i_{L 1}$ and $i_{L 2}$. In the proposed current balancer consisting of the three-leg converter, the active powers on the load side are exchanged in the three-leg converter. Thus only the reactive power flows into the DC capacitor $C_{D C}$. The required-rating of the DC capacitor $C_{D C}$ can be reduced by one-tenth as compared to that of the previously proposed current balancer. This demonstrates that the proposed current balancer is useful for the practical applications.

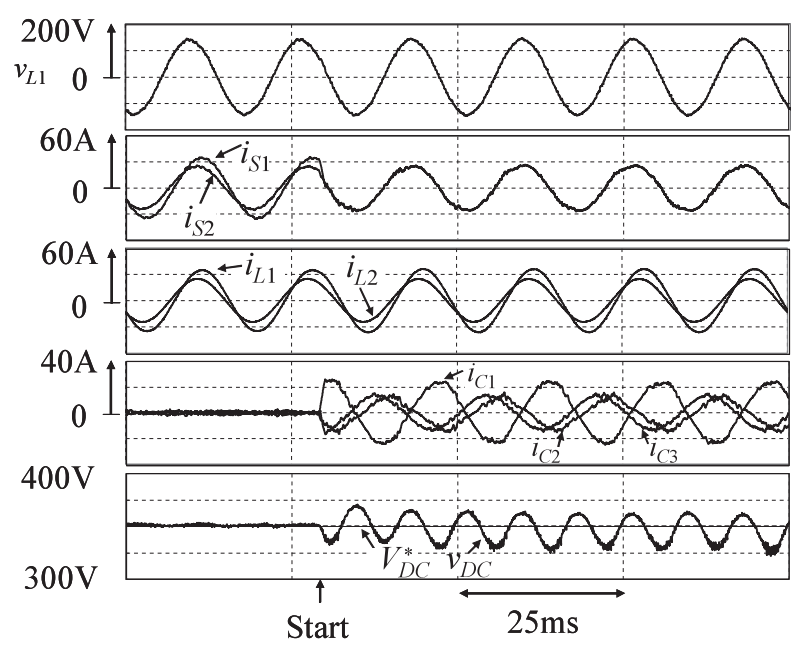

Fig. 2. Experimental waveforms for the constructed experimental model of Fig. 1 


\section{電源電圧と負荷電流の相関に着目した 単相三線式配電用電流バランサの制御法}

\begin{tabular}{|c|c|c|}
\hline 正 員 田中 & 俊彦* & 学生員 福井 \\
\hline 正員 平木 & 英治* & 正 員 渡邊 \\
\hline
\end{tabular}

\section{A New Current Balancer in Single-Phase Three-Wire Secondary Distribution Feeders Using the Correlation Coefficients}

Toshihiko Tanaka*, Member, Hirokazu Fukui*, Student Member, Eiji Hiraki*, Member, Shuuji Watanabe**, Member, Shinji Fukuma***, Non-member

This paper proposes a new current balancer in single-phase three-wire secondary distribution systems using the correlation coefficients. The components of the load currents correlative to the primary side voltage waveform, which correspond to the active currents, are detected in each feeder, then the non-active and unbalanced-active components are compensated on the source side. The balanced currents with unity power factor are obtained in each feeder. The basic principle of the proposed method is discussed in detail, and then confirmed by digital computer simulation. A proto-type experimental system is constructed and tested. Experimental results demonstrate that the balanced source currents with unity power factor are obtained in spite of unbalanced load currents.

キーワード：単相三線式配電, 電流バランサ, 相関係数, 有効電流, 不平衡状態, 平衡状態

Keywords: single-phase three-wire secondary distribution system, current balancer, correlation coefficient, active current, unbalanced condition, balanced condition

\section{1. まえがき}

家庭などの低圧配電として単相三線式配電が広く用いら れているが(1)，単相三線式配電においてアンバランスな負 荷状態での電流の不平衡が問題となる。このような両電圧 線電流の大きさの違いによって生じる電圧不平衡を解消す るため, 線路の末端に巻数比が 1 の単巻変圧器によるバラ ンサを設置し，電圧を等しくする方法が用いられている(2)。 この方法により，電圧の不平衡を解決することが可能とな

\footnotetext{
* 山口大学大学院 理工学研究科

干 755-8611 宇部市常盤台 2 丁目 16-1

Department of Electrical and Electronic Engineering, Yamaguchi University

2-16-1, Tokiwadai, Ube 755-8611

** 松江工業高等専門学校 電気工学科

干 690-8518 松江市西生馬町 14-4

Department of Electrical Engineering, Matsue National College of Technology

14-4, Nishiikuma, Matue 690-8518

*** 福井大学工学部 情報メディア工学科

干 910-8507 福井市文京 3-9-1

Department of Information Science, The University of Fukui

3-9-1, Bunkyou, Fukui 910-8507
}

る。一方，アンバランスな負荷状態を補償するため単相電 圧形ハーフブリッジインバータ 2 台を用いた電流バランサ が提案されている(3)(4)。提案された方式では，単相電圧形 ハーフブリッジインバータ直流キャパシタの中性点を利用 して中性線の電流を供給している。したがって, 各フィー ダ間の有効電力は単相電圧形ハーフブリッジインバータの 直流キャパシタを介して授受される。このため, キャパシ 夕電圧の脈動が大きくなり，これを抑制するため大容量の 直流キャパシタが必要となる。さらに, 各直流キャパシタ に流出入する電力が等しくならないため, それぞれの直流 キャパシタの電圧変動が異なるという問題点がある。

本論文では，3 アームを有する電圧形 PWM インバータ を用いた単相三線式配電用電流バランサを提案する。これ は, 各フィーダ間の有効電力は直流キャパシタを介すること なくインバータ内で授受される点に特長がある。このため, 先に提案されている方式に比較し, 直流キャパシタ容量を 大幅に低減することができる。電流バランサの制御法とし て電源電圧と負荷電流の相関に着目した方法を提案する ${ }^{(5)}$ 。 これは, 電源電圧と負荷電流の相関のある成分を検出する ことで電源側で力率が 1 でバランスした電源電流を得るこ とができる。はじめに，相関関数を用いた電流バランサの 
制御法について詳細に検討する。次に，電圧形 PWM イン バータの電力フローを詳細に検討する。提案した 3 アーム を有する電圧形 PWM インバータを用いた電流バランサで は, 有効電力がインバータ内で授受され, 無効電力のみが直 流キャパシタに流入することを示す。さらに，直流キャパ シタの蓄積エネルギーを検討し, 先に提案されている方式 に比べ直流キャパシタ容量を大幅に低減可能であることを 理論的に明らかにする。計算機シミュレーションおよび実 験結果より, 提案した 3 アームを有する電圧形 PWM イン バー夕により構成される単相三線式配電用電流バランサの 有効性を確認する。計算機シミュレーション結果および実 験結果から，先に提案された方式に比較し大幅に直流キャ パシタ容量を低減しながら，力率が 1 でバランスした電源 電流が得られることを明らかにする。

\section{2. 提案する単相三線式配電用電流バランサ}

〈2・1〉 システム構成 図 1 に, 本論文で提案する単相 三線式配電用電流バランサのシステム構成図を示す。配電 トランスの高圧側は $6,600 \mathrm{~V}, 60 \mathrm{~Hz}, 5.0 \mathrm{kVA}$ をベースとし ており，低圧側の定格は $105 \mathrm{~V}, 24 \mathrm{~A}$ である。表 1 に，図 1 で用いた変圧器の定数を示す。低圧側巻線は, 家庭に電力 を配電するために用いられ負荷として線形負荷を考慮して いる。電流バランサには 3 アームを有する電圧形PWM イ ンバータを用いており各アームがフィーダ 1, フィーダ 2 および中性線にそれぞれ接続されている。表 2 は，図 1 の 回路定数を示している。電圧形 PWM インバータは, 負荷 側電流の無効電流成分と有効電流成分のアンバランス分を 補償する。このため, 電源側で力率が 1 でバランスした電
流を得ることができる。文献 (3) および(4)では，単相電圧 形ハーフブリッジ PWM インバータを 2 台用いており, 直 流キャパシタの中性点を利用して中性線の電流を供給して いる。各フィーダの有効電力は直流キャパシタを介して授 受されるため, キャパシタ電圧の脈動が大きくなり，これ を抑制するため大容量の直流キャパシタが必要となる。さ らに，各直流キャパシタに流出入する電力が等しくならな いためそれぞれの直流キャパシタの電圧変動が異なるとい う問題点がある。本提案方式では, 3 アームの電圧形 PWM インバー夕を使用することでこれらの問題を解決している。 この点については，第 3 章で明らかにする。

$\langle\mathbf{2} \cdot \mathbf{2}\rangle$ 電源電圧と負荷電流の相関に着目した電流バラ ンサの制御法図 1 において, 高圧側電圧 $v_{S}(t)$ および 負荷電流 $i_{L 1}(t), i_{L 2}(t)$ と相関のある成分を検出する。高圧

表 1 図 1 で用いた変圧器定数

Table 1. Constants of the transformer used in Fig. 1.

\begin{tabular}{lc|c}
\hline \hline Shunt magnetizing reactance & $b_{0}$ & $4.51 \mu \mathrm{S}$ \\
\hline Shunt core loss resistance & $g_{0}$ & $0.849 \mu \mathrm{S}$ \\
\hline No load current & $I_{0}$ & $30.3 \mathrm{~mA}(0.04 \mathrm{pu})$ \\
\hline Winding resistance & $r_{1}+r_{2}$ & $180.1 \Omega(0.021 \mathrm{pu})$ \\
\hline Leakage reactance & $x_{1}+x_{2}$ & $121.3 \Omega(0.014 \mathrm{pu})$ \\
\hline
\end{tabular}

表 2 図 1 の回路定数

Table 2. Circuit constants for Fig. 1.

\begin{tabular}{ll|l}
\hline \hline Load1 & $L_{L}: 5.8 \mathrm{mH}$ & $L_{f}: 1.0 \mathrm{mH}$ \\
\cline { 3 - 3 } & $R_{L}: 2.9 \Omega$ & $C_{f}: 5.0 \mu \mathrm{F}$ \\
\hline Load2 & $L_{L}: 6.3 \mathrm{mH}$ & $L_{c}: 3.0 \mathrm{mH}$ \\
\cline { 3 - 3 } & $R_{L}: 4.9 \Omega$ & $C_{D C}: 750 \mu \mathrm{F}$ \\
\hline
\end{tabular}

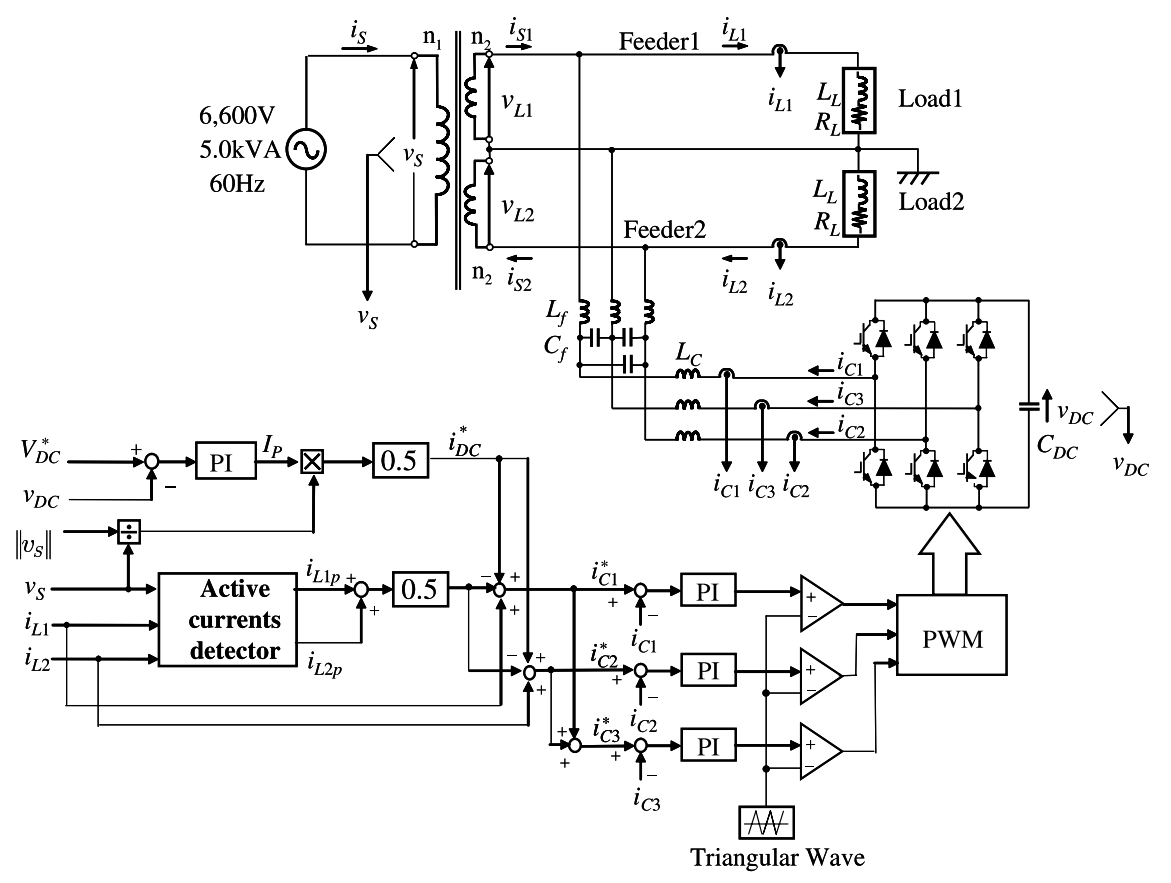

図 1 単相三線式配電用電流バランサのシステム構成図

Fig. 1. A Circuit diagram of the proposed current balancer in single-phase three-wire secondary distribution systems. 
側電圧 $v_{S}(t)$ および負荷電流 $i_{L 1}(t), i_{L 2}(t)$ が次式で与えら れるものとする。

$$
\begin{aligned}
& v_{S}(t)=\sqrt{2} V \sin \omega t \\
& i_{L 1}(t)=\sqrt{2} I_{1} \sin \left(\omega t-\phi_{1}\right) \\
& i_{L 2}(t)=\sqrt{2} I_{2} \sin \left(\omega t-\phi_{2}\right) .
\end{aligned}
$$

ここで, $v_{S}(t), i_{L 1}(t)$ および $i_{L 2}(t)$ のノルムはそれぞれ次式 で与えられる。

$$
\begin{aligned}
\left\|v_{S}(t)\right\| & =\sqrt{\frac{1}{T_{S}} \int_{t-T_{S}}^{t} v_{S}^{2}(t) d t} \\
\left\|i_{L 1}(t)\right\| & =\sqrt{\frac{1}{T_{S}} \int_{t-T_{S}}^{t} i_{L 1}^{2}(t) d t} \\
\left\|i_{L 2}(t)\right\| & =\sqrt{\frac{1}{T_{S}} \int_{t-T_{S}}^{t} i_{L 2}^{2}(t) d t}
\end{aligned}
$$

ただし， $T_{S}=1 / 60 \mathrm{~s}$ である。積分時間は， $T_{S} / 2$ に短縮で きる ${ }^{(6)}$ 。ノルムは関数の大きさを表し, 実効值に相当する。 $v_{S}(t)$ と $i_{L 1}(t)$ および $v_{S}(t)$ と $i_{L 2}(t)$ の内積は, それぞれ次式 で与えられる。

$$
\begin{aligned}
& \left\langle v_{S}(t), i_{L 1}(t)\right\rangle=\frac{1}{T_{S}} \int_{t-T_{S}}^{t} v_{S}(t) \cdot i_{L 1}(t) d t \\
& \left\langle v_{S}(t), i_{L 2}(t)\right\rangle=\frac{1}{T_{S}} \int_{t-T_{S}}^{t} v_{S}(t) \cdot i_{L 2}(t) d t
\end{aligned}
$$

内積は有効電力に相当する。ここで, 相関係数 $r_{1}, r_{2}$ は内 積をノルムの積で割ることにより次式で表される。

$$
\begin{aligned}
& r_{1}=\frac{\left\langle v_{S}(t), i_{L 1}(t)\right\rangle}{\left\|v_{S}(t)\right\|\left\|i_{L 1}(t)\right\|} \\
& r_{2}=\frac{\left\langle v_{S}(t), i_{L 2}(t)\right\rangle}{\left\|v_{S}(t)\right\|\left\|i_{L 2}(t)\right\|}
\end{aligned}
$$

相関係数 $r_{1}, r_{2}$ は関数どうしがどの程度似ているかを表す 尺度であり，大きさは $-1 \leq r \leq 1$ である。值が大きければ 関数間の相関が高い。また, 相関係数が 0 , すなわち電圧と 電流の内積が 0 ならば直交関係にある。したがって，相関 係数は力率を表す。(2) 式，(3) 式および(4) 式を用いること で，負荷側の有効電流はそれぞれ次式で表すことができる。

$$
\begin{aligned}
& i_{L 1 p}(t)=\frac{\left\langle v_{S}(t), i_{L 1}(t)\right\rangle}{\left\|v_{S}(t)\right\|^{2}} \cdot v_{S}(t) \\
& i_{L 2 p}(t)=\frac{\left\langle v_{S}(t), i_{L 2}(t)\right\rangle}{\left\|v_{S}(t)\right\|^{2}} \cdot v_{S}(t)
\end{aligned}
$$

図 1 において, 電源側の電流がバランス状態でかつ力率を 1 とするために $i_{S 1}(t)$ および $i_{S 2}(t)$ は，次式となればよい。

$$
\begin{aligned}
& i_{S 1}(t)=\frac{1}{2}\left\{i_{L 1 p}(t)+i_{L 2 p}(t)\right\} \\
& i_{S 2}(t)=\frac{1}{2}\left\{i_{L 1 p}(t)+i_{L 2 p}(t)\right\}
\end{aligned}
$$

したがって，電流バランサ出力電流指令值は次式となる。

$$
\begin{aligned}
& i_{C 1}^{*}(t)=i_{L 1}(t)-\frac{1}{2}\left\{i_{L 1 p}(t)+i_{L 2 p}(t)\right\} \\
& i_{C 2}^{*}(t)=i_{L 2}(t)-\frac{1}{2}\left\{i_{L 1 p}(t)+i_{L 2 p}(t)\right\} \\
& i_{C 3}^{*}(t)=-\left\{i_{C 1}^{*}(t)+i_{C 2}^{*}(t)\right\} \cdots \cdots \cdots \cdots
\end{aligned}
$$

負荷電流 $i_{L 1}(t)$ および $i_{L 2}(t)$ から， $i_{S 1}(t)$ および $i_{S 2}(t)$ を減 算したものを電流バランサ出力電流指令值として電流バラ ンサから出力することで, 電源側の電流 $i_{S 1}(t)$ および $i_{S 2}(t)$ を力率 1 の波形とすることができる。低圧側に高調波発生 源が存在する場合では, 低圧側電圧波形の歪が問題となる。 このため, 本論文では高圧側で電圧を検出している。しか しながら, 実用性の観点からは低圧側で電圧を検出するこ とが必要であり，PLLを用いた方式が有効と考えられる。 これらについては，稿を改めて報告したいと考えている。

$\langle\mathbf{2} \cdot \mathbf{3}\rangle$ 直流キャパシタ電圧一定制御 図 1 において, 負荷が変動した場合に有効電力が電圧形 PWM インバータ に流出入し直流キャパシタ電圧が変動する。この対策とし て，直流キャパシタ電圧一定制御ブロックを加える。図 2 に, 直流キャパシタ電圧一定制御ブロック図を示す。直流 キャパシタ電圧の指令值 $V_{D C}^{*}$ と検出したキャパシタ電圧 $v_{D C}$ の偏差を PI コントローラにより増幅し, 直流キャパシ 夕電圧を制御するための有効電流の振幅 $I_{P}$ を求める。ここ で, PI コントローラの伝達関数 $G(s)$ は次式で与えられる。

$$
G(s)=K_{P}\left(1+\frac{1}{s T_{I}}\right)
$$

本論文で用いた PI コントローラでは $K_{P}=0.2, T_{I}=50 \mathrm{~ms}$ としている。一方, 高圧側で検出した $v_{S}$ を電源電圧ノルム で割ることにより振幅 $\sqrt{2}$ の基準電圧を発生する。この基 準電圧と $I_{P}$ を乗算することで $v_{D C}$ を一定に制御するため の指令值 $i_{D C}^{*}$ を求める。この $i_{D C}^{*}$ を(7) 式で与えられる電 流バランサ出力電流指令值に加えることで, 電流バランサ の電流指令值 $i_{C 1}^{*}$ および $i_{C 2}^{*}$ としている。以上から, 直流 キャパシタ電圧一定制御法を用いた場合の電流バランサ出 力電流指令值は, 次式で与えられる。

$$
\begin{aligned}
& i_{C 1}^{*}(t)=i_{L 1}(t)-i_{S 1}(t)+0.5 i_{D C}^{*}(t) \\
& i_{C 2}^{*}(t)=i_{L 2}(t)-i_{S 2}(t)+0.5 i_{D C}^{*}(t)
\end{aligned}
$$

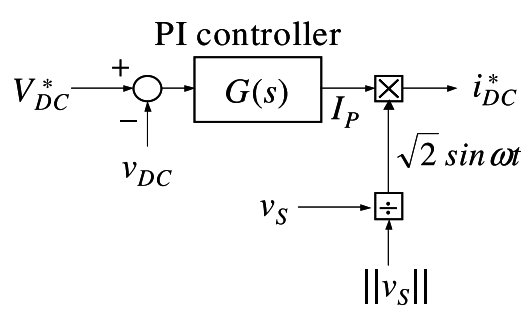

困 2 直流キャパシタ電圧一定制御ブロック図 Fig. 2. Block diagram of the constant dc capacitor voltage control. 


\section{3. 電カフローと直流キャパシタ容量の検討}

図 1 において, 電圧形 PWM インバータの直流キャパシ 夕に流入する電力フローを求め直流キャパシタ容量につい て検討する。各フィーダの負荷電流 $i_{L 1}(t), i_{L 2}(t)$ は次式で 与えられるものとする。

$$
\begin{aligned}
i_{L 1}(t) & =\sqrt{2} I_{1} \sin \left(\omega t-\phi_{1}\right) \\
& =\sqrt{2} I_{1}\left(\sin \omega t \cos \phi_{1}-\cos \omega t \sin \phi_{1}\right) \\
i_{L 2}(t) & =\sqrt{2} I_{2} \sin \left(\omega t-\phi_{2}\right) \\
& =\sqrt{2} I_{2}\left(\sin \omega t \cos \phi_{2}-\cos \omega t \sin \phi_{2}\right)
\end{aligned}
$$

(6) 式より，各フィーダの電源側電流 $i_{S 1}(t)$ と $i_{S 2}(t)$ は次式 となる。

$$
\begin{aligned}
i_{S 1}(t) & =i_{S 2}(t)=\frac{1}{2}\left\{i_{L 1 p}(t)+i_{L 2 p}(t)\right\} \\
& =\frac{\sqrt{2}}{2}\left(I_{1} \cos \phi_{1}+I_{2} \cos \phi_{2}\right) \sin \omega t
\end{aligned}
$$

さらに，(7) 式より電流バランサの出力電流は次式となる。

$$
\begin{aligned}
i_{C 1}(t)= & i_{L 1}(t)-i_{S 1}(t) \\
= & \frac{\sqrt{2}}{2}\left(I_{1} \cos \phi_{1}-I_{2} \cos \phi_{2}\right) \sin \omega t \\
& -\sqrt{2} I_{1} \sin \phi_{1} \cos \omega t \\
i_{C 2}(t)= & i_{L 2}(t)-i_{S 2}(t) \\
= & \frac{\sqrt{2}}{2}\left(-I_{1} \cos \phi_{1}+I_{2} \cos \phi_{2}\right) \sin \omega t \\
& -\sqrt{2} I_{2} \sin \phi_{2} \cos \omega t
\end{aligned}
$$

ここで, 低圧側電圧 $v_{L 1}(t)$ と $v_{L 2}(t)$ は次式で与えられるも のとする。

$$
v_{L 1}(t)=v_{L 2}(t)=\sqrt{2} V_{L} \sin \omega t
$$

以上より，三相電圧形インバータへ流入する電力 $p_{C}(t)$ は 次式となる。

$$
\begin{aligned}
p_{C}(t) & =v_{L 1}(t) \cdot i_{C 1}(t)+v_{L 2}(t) \cdot i_{C 2}(t) \\
& =-V_{L}\left(I_{1} \sin \phi_{1}+I_{2} \sin \phi_{2}\right) \sin 2 \omega t
\end{aligned}
$$

(14) 式より, 電圧形 PWM インバータの直流キャパシタに は無効電力のみが流入し, その周期は $T_{S} / 2$ である。この ことは, 各フィーダの有効電力は電圧形インバータを介し て授受が行われ直流キャパシタには流入しないことを示し ている。したがって，電流バランサとして動作する電圧形 PWM インバータの直流キャパシタ容量を大幅に低減でき る。一方，文献 (3) および (4) では各フィーダの有効電力は 直流キャパシタを介して授受されるため, キャパシタの脈
動が大きくなり，これを抑制するために大容量の直流キャ パシタが必要となる。

次に, 直流キャパシタ容量について検討する。ここで, $p_{C}(t)$ の充電あるいは放電期間中のエネルギー $\Delta W_{C}$ は

$$
\Delta W_{C}=\int_{0}^{T_{S} / 8} p_{C}(t) d t .
$$

となる。直流キャパシタ電圧の平均值が $V_{D C}$ であるとき, $\Delta W_{C}$ は次式で求められる。

$$
\left.\Delta W_{C}=\frac{1}{2} C\left\{\left(V_{D C}+\Delta V_{D C}\right)^{2}-V_{D C}^{2}\right)\right\}
$$

ただし， $\Delta V_{D C}$ はキャパシタ電圧の平均值からの変動分であ る。定常状態において, 直流キャパシ夕電圧の平均值に対 して $\pm 5 \%$ の変動を許容するものとする。Load1に $1.2 \mathrm{pu}$, 力率 $0.8, \operatorname{Load} 2$ に $0.8 \mathrm{pu}$, 力率 0.9 の負荷が接続されてい る場合に (15) 式で与えられる $\Delta W_{C}$ は $-3.57 \mathrm{~J}$ である。こ のとき, 直流キャパシ夕電圧の平均值を $350 \mathrm{~V}$ とすると直 流キャパシタ容量は次式となる。

$$
\begin{aligned}
C & =\frac{2 \times(-3.57)}{(350 \times 0.95)^{2}-350^{2}} \\
& =598 \mu \mathrm{F} \ldots \ldots \ldots \ldots .
\end{aligned}
$$

ここでは, 負荷急変時における直流キャパシタ電圧の変動 を $\pm 10 \%$ 以内とするために直流キャパシタ容量を $750 \mu \mathrm{F}$ に決定した。ここで, 直流キャパシタに蓄積されている静 電エネルギーについて検討する。文献 (3) および (4)では, 直流キャパシタ電圧が $400 \mathrm{~V}$ であり静電容量は $2200 \mu \mathrm{F}$ で ある。したがって, 静電エネルギーは $188 \mathrm{~J}$ となる。一方, 提案方式では静電エネルギーは次式で与えられる。

$$
\begin{aligned}
W & =\frac{1}{2} \times 750 \times 10^{-6} \times 350^{2} \\
& =45.9 \mathrm{~J} \ldots \ldots \ldots \ldots \ldots \ldots
\end{aligned}
$$

先に提案されている方式に比較し, 蓄積されている静電工 ネルギーを $1 / 4$ に低減することができる。この点からも提 案方式の有効性が明らかである。なお, 本論文では直流電 圧を $350 \mathrm{~V}$ としているが，実システムを考慮した場合には 直流電圧を低くすることが望ましい。この点については, 今後の重要な検討課題であると考えている。

\section{4. シミュレーション結果}

本論文で提案した電流バランサの制御法の有効性を確認 するために, 計算機シミュレーションを行った。シミュレー ションには, パワーエレクトロニクス用シミュレータ PSIM を用いた。単相三線式における中性線と各電圧側電線間の 負荷は，内線規程により“やむを得ない場合は設備不平衡 率を $40 \%$ までとすることができる”と定められている(7)。 設備不平衡率とは, 中性線と各電圧側電線間に接続される 負荷設備容量 $S_{1}, S_{2}$ [VA] の差と総負荷設備容量 $S_{A}$ [VA] の平均值の比で定義される。このとき, 設備不平衡率は次 式で与えられる。 


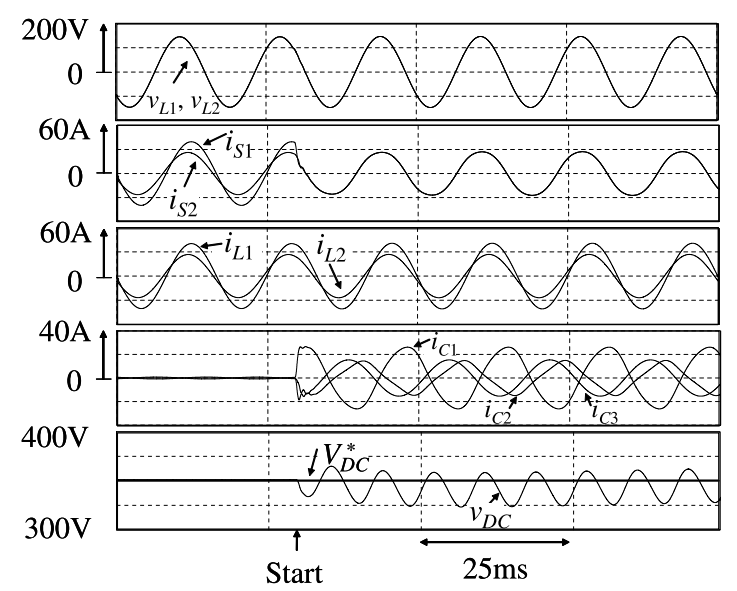

図 3 電流バランサ起動前後のシミュレーション波形

Fig. 3. Simulation waveforms for Fig. 1 before and after started.

設備不平衡率 $[\%]=\frac{S_{1}-S_{2}}{S_{A} \times 0.5} \times 100$

計算機シミュレーションでは, 表 1 の変圧器の定数を用い た。さらに，表 2 に示した回路定数としている。不平衡率 が $40 \%$ とするため Load 1 は $1.2 \mathrm{pu}$, 力率 $0.8, \operatorname{Load} 2$ は $0.8 \mathrm{pu}$, 力率 0.9 とした。

〈4・1〉 シミュレーション結果図 3 に, 電流バラン サ起動時のシミュレーション結果を示す。 $v_{L 1}$ は低圧側電 圧， $i_{S 1}, i_{S 2}$ は各フィーダの電源側電流を示している。電 流バランサの起動前はアンバランスな負荷状態であるため Load1 に流れる電流 $i_{L 1}$ と Load2 に流れる電流 $i_{L 2}$ の振幅 および位相が異なっている。一方，電流バランサの起動後 は, 電源側電流 $i_{S 1}$ と $i_{S 2}$ の振幅が等しくなっている。さら に, 電圧波形と比較し同相となっていることから力率が 1 であることが確認できる。また，キャパシ夕電圧 $v_{D C}$ から， 直流キャパシタ電圧一定制御法により指令值 $V_{D C}^{*}=350 \mathrm{~V}$ 付近に一定に制御されている。図 4 は, Load2 を一定とし た状態でLoad1 を $1.2 \mathrm{pu}$ から $0.6 \mathrm{pu}$ に急変させた場合の シミュレーション結果を示している。眓 4 より, 負荷が急 変した場合においても電流バランサにより各フィーダの電 源側電流 $i_{S 1}, i_{S 2}$ はバランスした状態となっている。図 3 および図 4 において，定常状態におけるキャパシタ電圧の 変動率は $\pm 4.9 \%$ である。また，負荷急変時では $+6.3 \%$ で あり，10\%以内となっている。このことから，(17) 式によ り決定したキャパシタ容量の妥当性が確認できる。

先に提案されている方式(3)(4)では, 各フィーダ間の有効 電力はインバータの直流キャパシタを介して授受されてい るため大容量の直流キャパシタが必要であり， $4700 \mu \mathrm{F} を$ 直列接続して用いている。本提案方式では, 直流キャパシ 夕には無効電力のみが流入するため直流キャパシタ容量を $750 \mu \mathrm{F}$ に低減できた。また，蓄積エネルギーは $46 \mathrm{~J}$ とな り $1 / 4$ に低減できた。

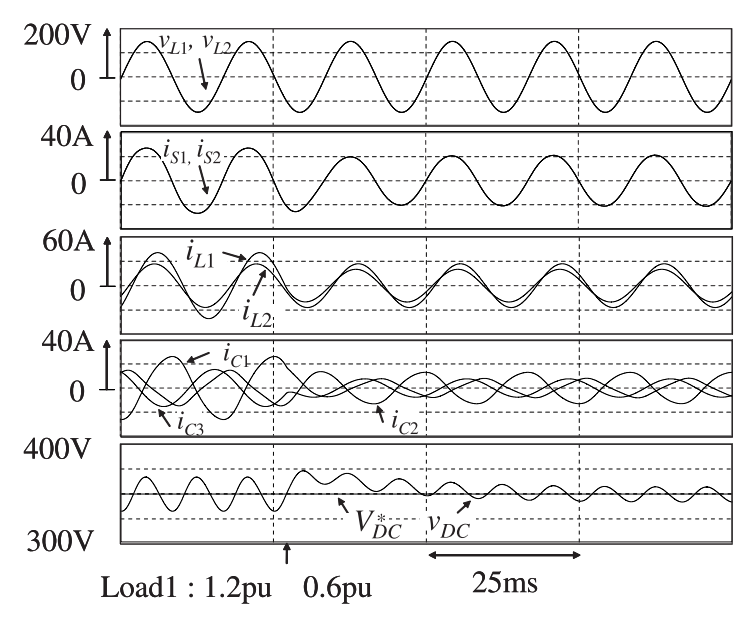

図 4 負荷急変時におけるシミュレーション波形

Fig. 4. Simulation waveforms for Fig. 1 with load variation of the Load1.

\section{5. 実験結果}

本論文で提案した電流バランサの制御法の有効性を確認 するために，実験装置を構成し実験による検討を行った。 図 1 では, 高圧側が $6600 \mathrm{~V}$ であり研究室レベルで実験装置 を構成するのは困難である。そこで, 一次側の電圧を $200 \mathrm{~V}$ として実験装置を構成した。

$\langle\mathbf{5} \cdot \mathbf{1}\rangle$ 実験装置の構成図 5 に, 単相三線式配電用 電流バランサの実験装置構成図を示す。電源トランスの一 次側は $200 \mathrm{~V}, 6.0 \mathrm{kVA}$ である。また, 二次側はそれぞれ $100 \mathrm{~V}, 30 \mathrm{~A}$ とし, それぞれ線形負荷が接続されている。 表 3 に, 実験で用いた変圧器定数を示す。また, 表 4 に実 験で用いた図 5 の回路定数を示す。シミュレーションと同 様に実験においても負荷はアンバランスな負荷状態となる ようにフィーダ 1 には $1.2 \mathrm{pu}$ で力率が 0.8 の負荷を接続し, フィーダ 2 には $0.8 \mathrm{pu}$ で力率が 0.9 の負荷を接続している。 このとき, 不平衡率はシミュレーションと同様に $40 \%$ で ある。

図 5 において, 電源電圧 $v_{S}$, 負荷電流 $i_{L 1}, i_{L 2}$ を検出し, $\mathrm{A} / \mathrm{D}$ 変換器を介してデジタル信号として, DSP に入力する。 DSP では, (7) 式を用いて電流バランサの出力電流指令值 $i_{C 1}^{*}, i_{C 2}^{*}, i_{C 3}^{*}$ を演算する。三角波比較方式 PWM を用いて, 各アームの出力電流を指令值に追従させているが, これら はすべて DSP 内で演算により実現している。ここで, 三角 波の周波数は $15 \mathrm{kHz}$ である。さらに, 図 2 に示した直流 キャパシタ電圧一定制御もDSPにより実現している。

$\langle\mathbf{5} \cdot \mathbf{2}\rangle$ 実験結果 図 6 に, 電流バランサ起動時の実 験結果を示す。 $v_{L 1}$ は低圧側電圧, $i_{S 1}, i_{S 2}$ は各フィーダの 電源側電流を示している。電流バランサの起動前は, アン バランスな負荷状態であるためLoad1 に流れる電流 $i_{L 1}$ と $\operatorname{Load} 2$ に流れる電流 $i_{L 2}$ の振幅および位相が異なっている。 これに対し電流バランサの起動後は, 電流バランサの補償 電流 $i_{C 1}, i_{C 2}, i_{C 3}$ により $i_{S 1}$ と $i_{S 2}$ の振幅が等しく力率が 


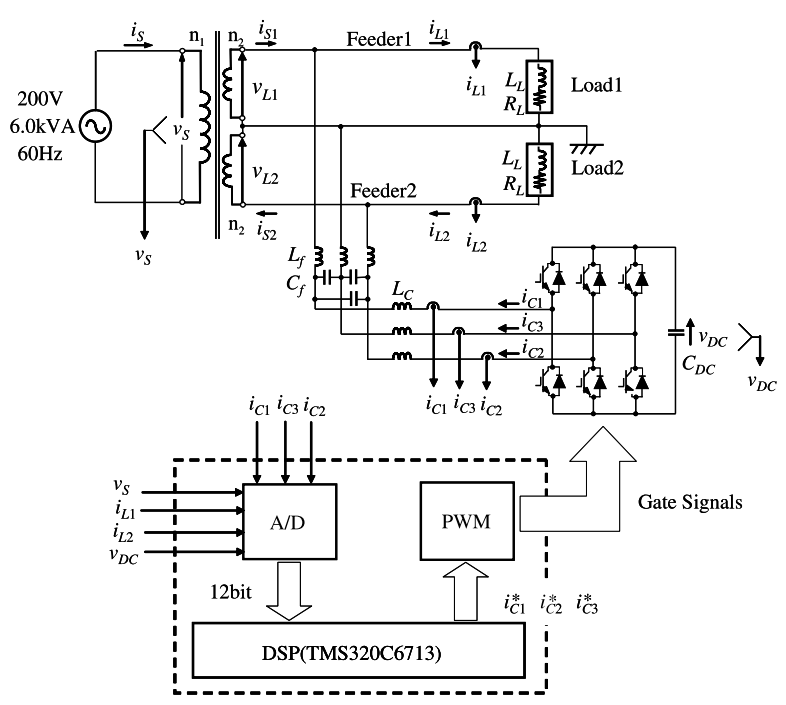

図 5 単相三線式配電用電流バランサの実験装置構成図

Fig. 5. Circuit diagram of the prototype experimental model for Fig. 1.

表 3 実験で用いた変圧器定数

Table 3. Constants of the transformer used in the experimental model of Fig. 5.

\begin{tabular}{lc|c}
\hline \hline Shunt magnetizing reactance & $b_{0}$ & $5.0 \mathrm{mS}$ \\
\hline Shunt core loss resistance & $g_{0}$ & $0.95 \mathrm{mS}$ \\
\hline No load current & $I_{0}$ & $0.99 \mathrm{~A}(0.033 \mathrm{pu})$ \\
\hline Winding resistance & $r_{1}+r_{2}$ & $0.131 \Omega(0.020 \mathrm{pu})$ \\
\hline Leakage reactance & $x_{1}+x_{2}$ & $0.0905 \Omega(0.014 \mathrm{pu})$ \\
\hline
\end{tabular}

表 4 図 5 の回路定数

Table 4. Circuit constants for Fig. 5.

\begin{tabular}{ll|l}
\hline \hline Load1 & $L_{L}: 6.4 \mathrm{mH}$ & $L_{f}: 1.0 \mathrm{mH}$ \\
\cline { 3 - 3 } & $R_{L}: 2.9 \Omega$ & $C_{f}: 4.7 \mu \mathrm{F}$ \\
\hline Load2 & $L_{L}: 6.3 \mathrm{mH}$ & $L_{c}: 3.0 \mathrm{mH}$ \\
\cline { 3 - 3 } & $R_{L}: 5.0 \Omega$ & $C_{D C}: 750 \mu \mathrm{F}$ \\
\hline
\end{tabular}

1 のバランスした電流が得られている。また，キャパシタ 電圧 $v_{D C}$ から，直流キャパシ夕電圧一定制御法により指令 值 $V_{D C}^{*}=350 \mathrm{~V}$ 付近に一定に制御されている。

次に，負荷急変時の実験結果を示す。図 7 は Load2 を一 定とし, Load1 を $1.2 \mathrm{pu}$ から $0.6 \mathrm{pu}$ に急変させた場合の実 験結果である。図 7 より，負荷が急変した場合においても 電流バランサにより各フィーダの電源電流 $i_{S 1}, i_{S 2}$ はバラ ンス状態となっている。図 6 および図 7 より，定常状態に おける直流キャパシタ電圧 $v_{D C}$ の変動率は $\pm 4.9 \%$ である。

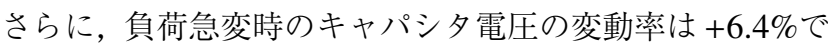
あり，10\%以内となっている。これらの結果はシミュレー ション結果と良く一致しており, (17) 式により決定したキャ パシタ容量の妥当性が確認できる。

$\langle\mathbf{5} \cdot \mathbf{3}\rangle$ 変換器容量の検討 ここで, 電流バランサと して動作する電圧形 PWM インバータの変換器容量につい て検討する。低圧側電圧 $v_{L 1}, v_{L 2}$, 電流バランサ出力電流 $i_{C 1}$ および $i_{C 2}$ の実効值をそれぞれ $V_{L}, I_{C 1}, I_{C 2}$ とすると,

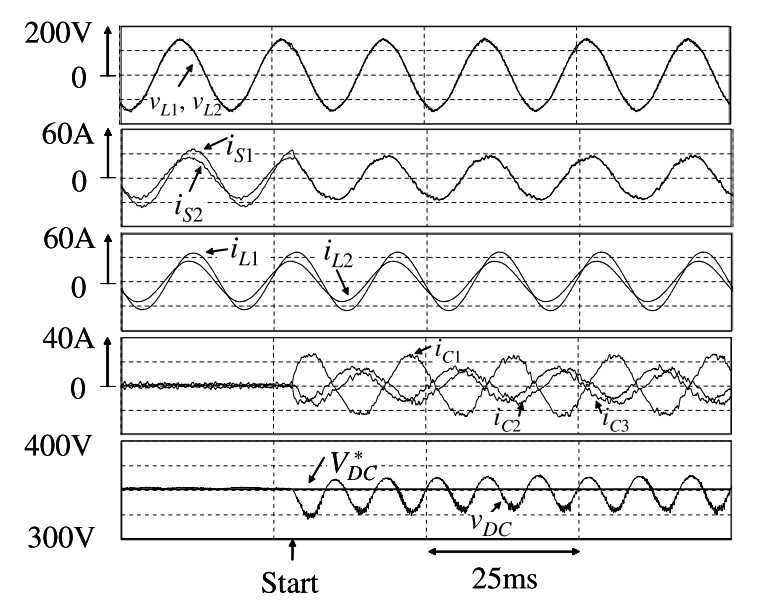

図 6 電流バランサ起動前後の実験波形

Fig. 6. Experimental waveforms for Fig. 5 before and after started.

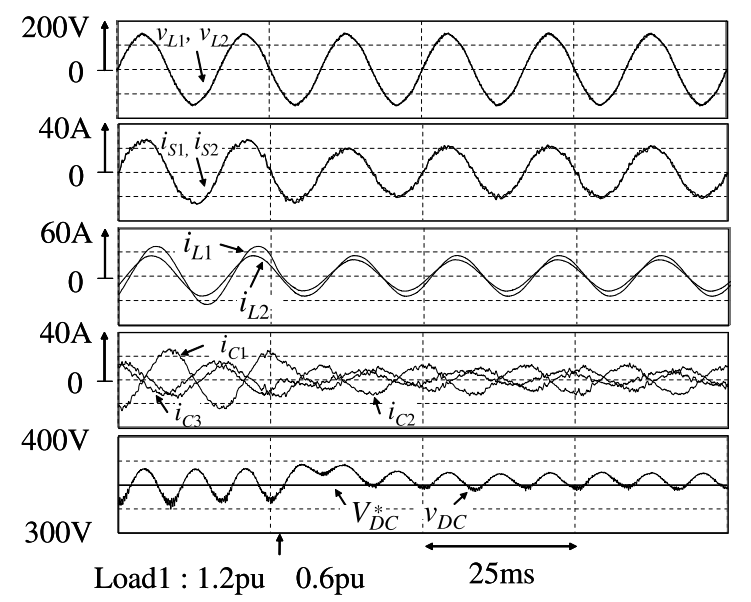

図 7 負荷急変時における実験波形

Fig. 7. Experimental waveforms for Fig. 5 with load variation of the Load1.

各フィーダの皮相電力 $S_{C 1}, S_{C 2}$ は次式で与えられる。

$$
\begin{aligned}
& S_{C 1}=V_{L} \cdot I_{C 1} \\
& S_{C 2}=V_{L} \cdot I_{C 2}
\end{aligned}
$$

したがって, 電流バランサの変換器容量 $S_{C}$ は次式で表さ れる。

$$
S_{C}=S_{C 1}+S_{C 2}
$$

図 6 の実験結果から， $i_{C 1}$ および $i_{C 2}$ の実効值はそれぞれ $17.0 \mathrm{~A}, 10.3 \mathrm{~A}$ である。(21) 式から変換器容量を求めると $2.7 \mathrm{kVA}$ となる。これは, 定格の約 $54 \%$ である。一方, 図 3 のシミュレーション結果では， $i_{C 1}$ および $i_{C 2}$ の実効值はそ れぞれ $18.7 \mathrm{~A}, 9.8 \mathrm{~A}$ であり変換器容量は $3.0 \mathrm{kVA}$ となる。 両者は良く一致しており, 実験結果の妥当性が確認できる。 なお，電流バランサとして動作する PWM インバータの変 換器容量の低減は今後の重要な検討課題であり, 稿を改め て報告したいと考えている。 


\section{6. むすび}

本論文では，3 アームを有する電圧形 PWM インバータ を用いた単相三線式配電用電流バランサを提案した。これ は, 各フィーダ間の有効電力は直流キャパシタを介するこ となくインバータ内で授受される。このため，直流キャパ シタ容量を大幅に低減することができる。電流バランサの 制御法として電源電圧と負荷電流の相関に着目した方法を 提案した。これにより力率が 1 でバランスした電源電流を 得ることができる。次に, 電圧形 PWM インバータの電力 フローおよび直流キャパシタ容量について検討し，先に提 案されている方式に比べ直流キャパシタ容量を大幅に低減 可能であることを明らかにした。さらに，直流キャパシタ の蓄積エネルギーを比較し, 先に提案されている方式に比較 し $1 / 4$ になることを明らかにした。計算機シミュレーショ ンおよび実験により本論文で提案した単相三線式配電用電 流バランサの有効性を検証した。シミュレーション結果お よび実験結果から，先に提案された方式に比較し大幅に直 流キャパシ夕容量を低減しながら, 力率が 1 でバランスし た電源電流が得られることを明らかにした。

(平成 18 年 10 月 2 日受付, 平成 19 年 1 月 20 日再受付)

\section{文献}

(1) 電気学会:「送電・配電」, オーム社, pp.162-165 (2001)

（2）林＼cjkstart泉：「電力系統」,明晃堂, pp.86-87 (1978)

(3) T. Fujita and S. Iida: "Trial Manufacture of Current Balancer for Singlephase Three-wire Distribution system", Papers of Technical Meeting on Semiconductor Power Conversion, SPC-04-3, pp.13-18 (2004-1) (in Japanese)

藤田崇之・飯田祥二 :「単相三線式配電系統用電流バランサの試作」, 電学半導体電力変換研資, SPC-04-3, pp.13-18 (2004-1)

(4) T. Fujita and S. Iida: "A Current Balancer in Single-Phase Three-Wire Distribution System”, IEEJ Trans. on IA, Vol.125, No.12, pp.1145-1152 (200512) (in Japanese)

藤田崇之・飯田祥二 : 「単相三線式配電系統用電流バランサの一方 式」, 電学論 D, 125, 12, pp.1145-1152 (2005-12)

(5) T. Tanaka, Y. Nishida, S. Fukuma, and S. Funabiki: "A Novel Harmonic Compersator for Consumer Electric Equipment Using the Correlation Function”, IEEJ Trans. on IA, Vol.123, No.11, pp.1377-1383 (2003-11) (in Japanese)

田中俊彦・西田雄治・福間慎治・船电繁之:「相関関数を用いた家電 機器が発生する高調波の抑制を目的としたアクティブフィル夕」, 電 学論 D, 123, 11, pp.1377-1383 (2003-11)

(6) I. Kawasaki, T. Tanaka, S. Fukuma, and S. Funabiki: "Discussions on Relationship between the Calculation Time of Harmonic Currents and the DC Capacitance of the Single-Phase Shunt Active Filter using the Correlation Function", Papers of Technical Meeting on Semiconductor Power Conversion, SPC-04-6, pp.31-36 (2004-1) (in Japanese)

川崎 勇・田中俊彦・福間慎治・船电繁之:「単相アクティブフィル 夕の高調波検出時間とコンデンサ容量の検討」, 電学半導体電力変換 研資, SPC-04-6, pp.31-36 (2004-1)

（7）電気技術基準調查委員会：「内線規程 JEAC 8001-1995」, 日本電気協 会. p. 20

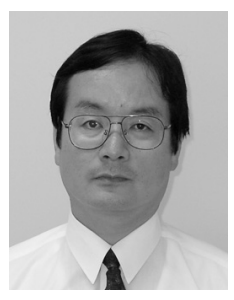

（正員） 1984 年 3 月長岡技術科学大学大学院工 学研究科修士課程修了。同年 4 月東洋電機製造 (株) 入社。職業能力開発大学校（現, 職業能力 開発総合大学校）電気工学科講師を経て 1997 年 4 月島根大学総合理工学部電子制御システム工学 科助教授, 2004 年 12 月山口大学工学部電気電子 工学科教授, 2006 年 4 月大学院理工学研究科情 報・デザイン工学系専攻教授に配置換え，現在に 至る。博士 (工学)。半導体電力変換器が発生する高調波とその抑制 法, 環境修復システムへのパワーエレクトロニクス応用, 微生物処理 を含む高度水処理などの研究に従事。2002 年中国電力技術研究財団 優秀研究賞, 2003 年電気設備学会学術部門論文賞受賞。電気設備学 会, IEEE 会員。

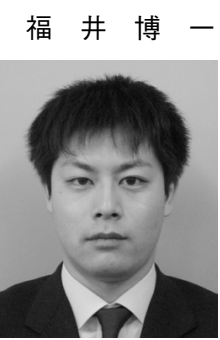

（学生員） 2001 年 4 月島根大学総合理工学部電 子制御システム工学科入学。2005 年 3 月同卒業。 同年 4 月山口大学大学院理工学研究科電気電子工 学専攻入学, 現在に至る。相関関数を用いた単相 三線式配電用バランサに関する研究に従事。
平 木 英 治

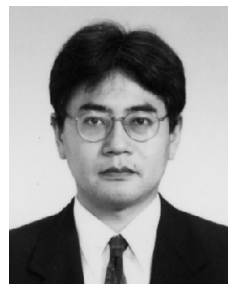

（正員） 1990 年大阪大学大学院基礎工学研究科 博士前期課程電気工学専攻修了。(株) マツダ技 術研究所を経て, 1995 年 12 月山口大学工学部電 気電子工学科助手, 2006 年 4 月大学院理工学研 究科情報・デザイン工学系専攻助手に配置換え, 2007 年 3 月同助教授, 現在に至る。博士 (工学)。 主にソフトスイッチング電力変換システムを含む エネルギーエレクトロニクスに関する研究と教育 に従事。IEEE，パワーエレクトロニクス学会各会員。電気学会調査専 門委員会委員。

渡 邊 修 治 (正員) 2003 年 3 月山口大学大学院理工学研究

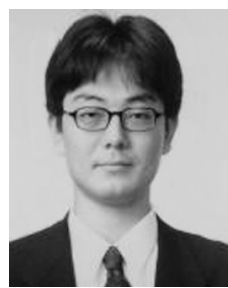
科博士後期課程電気システム工学専攻修了。1999 年 4 月松江工業高等専門学校電気工学科助手, 現 在同講師。博士 (工学)。多重化電力变換器のアド バンスト制御応用，および電力系統における障害 電流補償に関する研究と教育に従事。電気学会, 及びパワーエレクトロニクス研究会の各正会員。

福 間 慎 治 (非会員) 1999 年 3 月長岡技術大学大学院工学

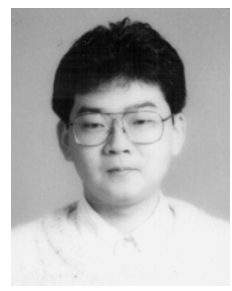
研究科情報・制御工学専攻博士後期課程修了。同 年 4 月同大学工学部電気系助手。同年 9 月通信 放送機構研究フェロー兼務。2000 年 4 月島根大学 総合理工学部電子制御システム工学科助手。2004 年 4 月福井大学工学部情報メディア工学科講師, 現在に至る。博士 (工学)。ディジタル信号処理, 適応信号処理, 画像符号化, 特定用途向けディジ タル画像処理システム構築の研究に従事。電子情報通信学会, 計測自 動制御学会, IEEE 会員。 